\title{
A STUDY ON ECONOMIC BENEFITS OF ISO CERTIFICATION
}

\section{TO MANUFACTURING UNITS}

\author{
MOHANRAJ. $\mathrm{K}^{1}$ \& RAVI KUMAR ${ }^{2}$ \\ ${ }^{I}$ Department of Management and Commerce, Amrita School of Arts and Sciences, Amrita Vishwa \\ Vidyapeetham, Mysore, Karnataka, India \\ ${ }^{2}$ Assistant Professor, Department of Management and Commerce, Amrita School of Arts and Sciences,
}

Amrita Vishwa Vidyapeetham, Mysore, Karnataka, India

\begin{abstract}
ISO is a Non-governmental and independent organization where it voluntarily establishes the standards for the improvement of the organization for the quality consciousness for the customers. The main benefit for seeking ISO certification by the organizations is for the Customer relationship management by the firms. This study is conducted to know whether the ISO certification makes the firm more efficient by analysing before and after certification of ISO. The descriptive research method is adopted to find out the benefits of the adoption of ISO. The prime outcomes of the study show the selected company has made considerable progress in the areas of productivity, profitability and other administrative areas on the adoption of ISO standards compare to before the adoption of the organization.

KEYWORDS: ISO, Manufacturing Firm, Profitability \& Administrative Operation
\end{abstract}

Received: Dec 24, 2018; Accepted: Jan 14, 2019; Published: Feb 04, 2019; Paper Id.: IJMPERDAPR20195

\section{INTRODUCTION}

From the year 1987 the ISO 9000 standard for quality management system has made a huge impact on the economy. There are firms seeking certification by the standard, the standards are being adopted globally by the firms itself for certification. The adoption of ISO is increasing globally among the firms according to its standards. The implementation of ISO represents the transformation from a poor performance of the management to a total quality management of the organisation. The economic contribution of standards to the economy and company will improve the productivity and performance in all the sectors. The main purpose of the ISO is to make it a quality management and it deals with the overall management of an organisation. When ISO standards are applied choosing quality goods and services becomes easier. ISO standards make the world safer, cleaner and more efficient, from food safety to computers, from health care to new technology. ISO gives positive support for utilising the wealth of the firms effectively.

"Economic Benefits are benefits that can be quantified in terms of money generated such as net income, revenue, etc. Economic benefits can be measured and used in business decisions, policy decisions and market analyses. Business will use measures such as net income, net cash flow, or return on investment as measure for economic benefits. Policy makers will likely use consumer and producer surplus as economic benefit measures" [study.com] in the light of the above economic benefits to the organization, the present study tries to understand the economic benefits derived by adopting ISO standards at selected manufacturing units in Mysore. 


\section{REVIEW OF LITERATURE}

- U. H. Acharya and Sanjit Ray (2000) has done a study on "ISO 9000 certification in Indian industries" in this they have discussed about the various criteria like benefits of certification, the hurdles faced on the path of certification likely the study is planned and conducted. And it also gives the suggestions for improving effectiveness of the industries like quality policy implementing, customer complaints, auditee may take over the compliant and make benefits according to the customer satisfaction.

- Shannon. W, Anderson. J. Daniel Daly and Marilyn F Johnson (1999)has undergone a study on "Why firms seek ISO 9000 certification" they say's firms are not imposed by anyone to seek certification in the industry, they voluntary obtain certification because the better alternative may exist to control the mechanisms of the market where the quality management process occurs. They have said that the customer may indicate regulatory and inadequate compliances when the quality signals of the management are smaller. The main motive is to know about the ability to examine the value of the firm's quality and its setting up in the industry.

- Jason A. Briscoe, Stanley E. Fawcett, and Robert H. Todd (2005) has conducted a study on "The implementation and impact of ISO 9000 among Small Manufacturing Enterprises" this paper focuses on the Small Manufacturing Firm where the successful implementation of ISO standards and its barriers to ISO certification are done. By implementing it the firm will influence positive needs to be changed, establishing a quality culture, changes in the infrastructure. This concludes with the key saying that how ISO adoption can be made by reducing the behaviour that inhibit the adoption of ISO strategy where the successful environment is made with the quality conscious.

- James P, Mary Ann T. Walsh and Kim La Scola Needy (2015) "An Examination of the Economic Benefits of ISO 9000 and the Baldrige Award to Manufacturing Firms" this paper says about the economic benefits of the financial data of manufacturing companies which are certified. He also states about the benefit of cost of the company which is registered under ISO 9000, it's calculated to know the annual cost to know their benefits to stay for a positive result of the company. And he also examines from the Baldrige Award Winners whether the benefit of receiving ISO 9000 is economically attractive to the business or not. He concludes with saying that the survey conducted will be useful for implementing the quality in it.

- Ann Terlaak, and Andrew A. King (2005) "The effect of certification with the ISO 9000 Quality Management Standard" this paper says about the management standards of ISO 9000, and it also becomes the credibility for communicating to buyers of the company. This study says about the value of agents of the institution and it is the signal of superior but unobservable attributes which provide benefits. He concludes by saying that it is useful for managers and institutional agents, whereas to reduce their problems on management standards.

- Mary J Benner, Francisco M Veloso (2008) "ISO 9000 Practices and financial performance" a technology coherence perspective this paper says about the implementation of ISO in a sector and its performance where it is organizational set up is made. It also says about the reduction of cost in it by improving the operational efficiency. It says the waste and costs reduction in it since the production of defect-free products, standardized procedures are formed for the effectiveness of the organization. He concludes by saying that this study is made for the improving the organization in process management and strategy stream. 
- Prof. Inaki Heras, Prof. Marti Casadesus, Prof. Carlos Ochoa has made an empirical study on the "Effects of ISO 9000 certification on companies' profitability" this paper says about the effects on certified companies of the implementation and certification according to ISO 9000 standards. Benefits towards the implementation of ISO 9000 Standards effect towards the profitability of the business and also its analyses on the economic outcomes of the certified and non-certified companies in the region of the study conducted.

- P. Padma, L. S. Ganesh and C. Rajendran (2008) "A Study on the critical factor of ISO 9001:2000 and organizational performance of Indian manufacturing firms" this paper says about the standards of quality management systems of the firms' total quality management where in which it includes the critical factors and indicators of organizational performance. Where to analyse the relationship of firm attributes with critical factors and also with the attributes of firms with the indicators of organizational performance.

- Joseph Iwaro and Abrahams Mwasha (2012) "The Effect of ISO Certification on Organization workmanship performance" this paper says about the workmanship of more construction industry with a comparison of ISO Certified organizations and non-ISO organizations. Where this is a case study of the specific organization where the implementation of ISO 9001 is happening in comparing with the organization performance where the implementation of ISO 9001 has not been held. This paper gives the result of the workmanship of all the industries which is certified and not certified under ISO.

- Durai Anand Kumar and Dr. V. Balakrishnan(2011) “A Study on ISO 9001 Quality Management System Certifications - Reasons behind the failure of ISO certified, certifications" this paper is prepared to know about the effectiveness of the industry which is certified under ISO 9001. This study will be useful for all the types of organization to evaluate the effectiveness and identify the quality, performance and develop the strategic management system of the organization which is certified under ISO.

\section{OBJECTIVES}

- To study the impact of ISO standards on company profits, costs and revenue management.

- To study the change in Productivity levels of the firm on the adoption of ISO standards.

- To identify the changes in Administrative operations of the firm on adoption of ISO standards.

\section{METHODOLOGY}

\section{Need for the Study}

There are many Economic Benefits in case of an ISO registered company. Now-a-days most of the companies seek certification because of the competitor company to compete with them in the market, as the certification lead to overall development of the firm. The ISO plays a vital role in it. Hence it becomes important to understand how ISO extends the economic benefits to the manufacturing firm.

\section{Area Selected for the Study and Research Method}

The study is made at selected firms in Mysore city, as there is development of industrial area in four phases and most of the units are registered under ISO standards. 
The descriptive research method is adopted as the study tries to understand the changeover in productivity on adoption of ISO standards on the previous data.

\section{Source of Data Collection}

As the study tries to understand the changes over the productivity of adoption of ISO standards, previous reports are taken as a prime source of information for comparing productivity component before and after adoption of ISO standards. Accordingly, secondary source of information is adopted for the study.

\section{SCOPE OF THE STUDY}

- $\quad$ Profit after implementation of ISO is increased or decreased.

- Sale of the product is increased or decreased.

- $\quad$ Productivity is maximised or minimised.

- Dealers and the external suppliers for the sales is improved or not.

- Technological differences before and after certification.

\section{CONCEPTUAL FRAMEWORK}

\section{About ISO}

ISO is a non-governmental, independent organization with the members of 162 bodies around the nation. With the members of ISO, they adopt the experts around the nation for the challenges faced globally for its improvement in the standards and also they voluntarily support innovation in the terms of the products and services, systems, quality and efficiency. In which they facilitate the international trade with its standards on every industry from safety to technology, where it impacts lies with everyone and everywhere.

\section{Benefits of the ISO}

In the last 50 years ISO has made a family of standards, to ensure the quality and safety among the ISO certified companies' products which is used by the consumers. Which make the customers feel that the management system is approved by ISO standards. And also the companies will be having the global recognition for its better management of the ISO standards.

\section{ANALYSIS AND INTERPRETATION}

\section{To Study about the Profitability of the Firm before and after Certification}

Table 1: Shows about the Profitability before and after Certification

\begin{tabular}{|c|c|c|c|}
\hline \multicolumn{2}{|c|}{ Before ISO 9000 Certification } & \multicolumn{2}{c|}{ After ISO 9000 Certification } \\
\hline Year & Profitability & Year & Profitability \\
\hline 2012 & $6.1 \%$ & 2015 & $7.65 \%$ \\
\hline 2013 & $6.19 \%$ & 2016 & $8.55 \%$ \\
\hline 2014 & $6.22 \%$ & 2017 & $8.70 \%$ \\
\hline
\end{tabular}

[Source: company records]

The above table shows the assessments of the manufacturing Industry. These data are statistically different among the industries' profitability before and after certification of ISO. Where the ISO Certified firms are considered and the profitability of the firms is collected to analyse the view of ISO on manufacturing firms, where to know the standards of 
the ISO makes the firm more effective and profitable after implementing it in the firm. The firms also say that because of implementing ISO standards in firm the quality of the firm is increasing and the profitability is also increasing where compared to the previous years of the profitability.

To Compare about the Revenue Performance before and after Certification of the Firm

Table 2: Shows the Revenue of the Firm before and after Certification

\begin{tabular}{|c|c|c|c|c|}
\hline \multirow{2}{*}{ Particulars } & \multicolumn{2}{|c|}{ Before ISO 9000 Certification } & \multicolumn{2}{|c|}{ After ISO 9000 Certification } \\
\hline & Product1 & Product 2 & Product 1 & Product 2 \\
\hline Price & 80 & 75 & 90 & 85 \\
\hline Quantity Sold & 20 & 55 & 37 & 52 \\
\hline Mark-Up & 20 & 10 & 20 & 15 \\
\hline Shipping Charges & 25 & 25 & 25 & 25 \\
\hline Profit & 41 & 32.5 & 43 & 37.6 \\
\hline Net Income & 820 & 1787.5 & 1591 & 1955.2 \\
\hline Total Revenue & 1140 & 2200 & 2257 & 2618.2 \\
\hline
\end{tabular}

[Source: company records]

The above table shows that the Revenue of the firm before and after the Certification of ISO 9000. The firm manufactures two products (Product 1, Product 2) and listed in the table 2 with all of the particulars of the products from consumption of Raw material till the sale of last produced product in the market. And then the revenue for the product is analysed by the calculation of its sales in the market, according to the amount of production of the product. On comparing the table of both the products before and after certification of ISO 9000 the performance of the products after the ISO Certification is good where the ISO 9000 has quality conscious on the process of installation of it in the firm.

\section{To Understand about the Productivity Level after Adopting ISO Certification}

In this category the firm's productivity is analysed after the certification of ISO 9000. The productivity of the firms will affect the nations in the terms of economic growth. Productivity describes the various measures of the efficiency of production. The productivity is measured in terms of the output on the amount of input for production. The productivity of firms can also change the performance of profit.

Table 3: Shows the Productivity Level after Adoption of ISO

\begin{tabular}{|c|c|c|c|c|}
\hline $\begin{array}{c}\text { ISO } \\
\text { Certification }\end{array}$ & $\begin{array}{c}\text { Improvement in } \\
\text { Manufacturing } \\
\text { Techniques }\end{array}$ & $\begin{array}{l}\text { Customers } \\
\text { Satisfaction }\end{array}$ & Technology & Aiding of Employees \\
\hline $\begin{array}{l}\text { ISO } 9000 \\
\text { Certified }\end{array}$ & $\begin{array}{l}\text { The business plan is } \\
\text { taken and analysed } \\
\text { and updated with the } \\
\text { new idea of } \\
\text { development over } \\
\text { production. So that } \\
\text { the quality of the } \\
\text { product increases, and } \\
\text { the wastage in } \\
\text { production } \\
\text { decreased has }\end{array}$ & $\begin{array}{l}\text { Internal } \\
\text { The orders from the } \\
\text { existing customer } \\
\text { increases and also } \\
\text { new customers are } \\
\text { gained. } \\
\text { External } \\
\text { The outside customers } \\
\text { who use the product } \\
\text { and service increases } \\
\text { due to the Quality of } \\
\text { the product on } \\
\text { adoption of ISO } \\
\text { standards }\end{array}$ & $\begin{array}{l}\text { New technology is } \\
\text { found for the } \\
\text { production process } \\
\text { with the help of R\&D } \\
\text { development in the } \\
\text { firm }\end{array}$ & $\begin{array}{l}\text { On the adoption of } \\
\text { ISO } 9000 \text { Standards } \\
\text { the employees of the } \\
\text { firm by extending } \\
\text { training which in turn } \\
\text { has helped in quality } \\
\text { service delivery }\end{array}$ \\
\hline
\end{tabular}

[Source: company records] 
To Know the Administrative Operations Changes and Impact on the Firms Performance

Table 4: Shows the Administrative Operation after ISO Certification

\begin{tabular}{|l|l|l|}
\hline \multicolumn{1}{|c|}{$\begin{array}{c}\text { ISO } \\
\text { Certification }\end{array}$} & \multicolumn{1}{|c|}{ Internal Audit } & \multicolumn{1}{|c|}{ Human Resources } \\
\hline & $\begin{array}{l}\text { HR department is } \\
\text { It makes the firms to review the } \\
\text { business process to analyse the to analyse the } \\
\text { effectiveness and makes the system to } \\
\text { ISO } 9000 \\
\text { Certified } \\
\text { plan. }\end{array}$ & $\begin{array}{l}\text { levelopment of the } \\
\text { firm. It focusses } \\
\text { mainly on the } \\
\text { employee's welfare } \\
\text { and the society. }\end{array}$ \\
\hline
\end{tabular}

[Source: company records]

\section{CONCLUSIONS}

In this competitive business environment, it is difficult to sustain and succeed for business houses. ISO is like a guide to upgrade companies to the standards that make them to compete and succeed. Adoption of ISO leads to a systematic method of working and adoption of standard practices that will reflect as quality goods and services. The above study narrates about the changes in the qualitative aspect, productive aspect and profitability aspects in turn all the economic benefits that the organization gained on the adoption of ISO standards.

\section{REFERENCES}

1. U.H.Acharaya\& Sanjit Ray (2000) “ISO 9000 Certification in Indian Industries:a survey”Total Quality Management, Vol. 11, No. 3, 2000, 261- 266

2. Shannon. W, Anderson. J. Daniel Daly and Marilyn F Johnson (1999) “Why firms seek ISO 9000 certification”, Production And Operations Management Vol. 8, No. 1, Spring 1999 Printed in U.S.A.

3. Jason A. Briscoe, Stanley E. Fawcett, and Robert H. Todd (2005) "The implementation and impact of ISO 9000 among Small Manufacturing Enterprises", Journal of Small Business Management 2005 43(3), pp. 309-330

4. James P. Wilson, Mary Ann T. Walsh \& Kim LaScola Needy (2003) “An Examination of the Economic Benefits of ISO 9000 and the Baldrige Award to Manufacturing Firms", Engineering Management Journal, 15:4, 3-10, DOI: 10.1080/10429247.2003.11415220

5. Ann Terlaak, and Andrew A. King (2005) "The effect of certification with the ISO 9000 Quality Management Standard"Journal of Economic Behavior \& Organization Vol. 60 (2006) 579-602

6. Mary J Benner, Francisco M Veloso (2008) “ISO 9000 Practices and financial performance”Journal of Operations Management 26 (2008) 611-629

7. Toby, A. J. (2014). Working capital management policy and corporate profitability of Nigerian quoted companies: a sectoral analysis. International Journal of Financial Management (IJFM), 3(1), 9-20.

8. P. Padma, L. S. Ganesh \& C. Rajendran (2008) "A study on the critical factors of ISO 9001:2000 and organizational performance of Indian manufacturing firms", International Journal of Production Research, 46:18, 4981-5011, DOI: $10.1080 / 00207540600793299$

9. Joseph Iwaro \& Abrahams Mwasha (2012) "The Effects of ISO Certification on Organization Workmanship Performance", Quality Management Journal, 19:1, 53-67, DOI: 10.1080/10686967.2012.11918527 
10. Durai Anand Kumar and Dr. V. Balakrishnan (2011) “A Study on ISO 9001 Quality Management System Certifications Reasons behind the failure of ISO certified certifications" Global Journal of Management and Business Research Volume 11 Issue 9 Version 1.0 September 2011 Type: Double Blind Peer Reviewed International Research Journal Publisher: Global Journals Inc. (USA) Online ISSN: 2249-4588 \& Print ISSN: 0975-5853

11. Deshmukh, G. P., Patil, C., \& Deshmukh, M. Lean Techniques In Manufacturing Industry.

12. Casadesus M, and Karapetrovic S.(2005), "An empirical study of the benefits and costs of ISO 9001:2000 compared to ISO 9001:1994, Total Quality Management", Vol.16 No.1, pp 105-20. Print

13. Kartha C P (2004), “A Comparison of ISO 9000-2000 Quality system standards, QS 9000, ISO/TS 16949 and Baldrige Criteria”, The TQM Magazine, Vol.16 No.5, pp 331-340

14. Viadiu F.M, and Fransi E.C (2005), "A study on the ISO 9000 certification process: Consultant profiles and company behaviour”, Managing Service Quality, Vol.15 No.3, pp 290-305

15. C. I, Aashish and M. S, Divya, A Study on the Food Processing Industry and Its Quality Conscious Effect (April 30, 2018). International Journal of Mechanical and Production Engineering Research and Development, Vol. 8, Issue 2, Apr 2018, 1161 1170. Available at SSRN: https://ssrn.com/abstract=3275189 or http://dx.doi.org/10.2139/ssrn.3275189

16. Ravi Kumar, Stand Up India Programme - An Address To Financial Problems Of Micro And Small Scale Manufacturing Andproduction Units, International Journal of Mechanical and Production Engineering Research and Development (IJMPERD) ISSN (P): 2249-6890; ISSN (E): 2249- 8001 Vol. 8, Issue 1, Feb 2018, 1271-1278. 
